\title{
GÊNERO DISCURSIVO, ESTILO, AUTORIA
}

\author{
DISCURSIVE GENRE, STYLE, AUTHORSHIP
}

\author{
Miriam Bauab Puzzo* \\ Universidade de Taubaté, Taubaté, SP, Brasil
}

Resumo: 0 objetivo deste artigo é discutir o uso estilístico da língua em enunciados concretos, na perspectiva dialógica da linguagem. Para discutir essa questão, foi selecionado o artigo de opinião "Notas sem confete", de Fernando de Barros e Silva, veiculado na Folha de S. Paulo, de 6 de fevereiro de 2008, observando como o tema, a proposta do autor e sua relação com o contexto imediato criam uma forma expressiva diferenciada, rompendo com a forma composicional e 0 estilo genérico do artigo. Nessa perspectiva andlítica, procura-se demonstrar que 0 estilo não se reduz ao sujeito-enunciador, mas resulta das relações dialógicas que o enunciador mantém com o leitor presumido e com o contexto social. Como postula Bakhtin, 0 estilo decorre dá relação dialógica mantida entre 0 enunciador e 0 grupo social (BAKHTIN, 2003). Destaca-se, portanto, a questão da autoria em gêneros permeáveis à inflexão subjetiva, alterando seu formato.

Palavras-chave: teoria dialógica; artigo de opinião; estilo; gênero discursivo; autoria.

\begin{abstract}
This article aims to discuss the stylistic use of language in concrete utterances according to the dialogic theory of language. To accomplish this purpose it was selected Fernando de Barros Silva's article published in Folha de S. Paulo, february 06, 2008, observing how the theme, the author purpose and the relationship with the immediate context create a peculiar stylistic and compositional form, breaking the compositional form and the generic style of the opinative article. In this analytical perspective, it seeks to demonstrate that the style cannot be reduced to the author inspiration, but it results from dialogic relationships between the author, the presumed reader and the social context. So as Bakhtin posits, the style results from the dialogic relationship maintained between the utterer and his social group (BAKHTIN, 2003). It highlights, therefore, the question of authorship in subjective genres that are affected by the subjective inflection changing its shape.
\end{abstract}

Keywords: Dialogical Theory; Opinion article; Style; Discursive Genre; Authorship.

* Professora doutora da Universidade de Taubaté - UNITAU, Taubaté, Brasil; puzzo@uol.com.br 
Linha D’Água (Online), São Paulo, v. 28, n. 2, p. 172-189, dez 2015

\section{Introdução}

O estilo representa um dos aspectos cruciais na composição dos enunciados e é um dos tópicos que acompanha as reflexões sobre a estética literária e sobre os gêneros desde a Antiguidade. Seguindo uma tradição clássica, a concepção de estilo reduzia-se ao emprego dos tropos e figuras de linguagem, conforme ditavam os tratados relativos à arte poética, cujo objetivo era orientar os autores na arte de bem escrever. Com o Romantismo e a ruptura com os modelos clássicos, o estilo passou a ser considerado um fator preponderante na obra de arte. Entendido nessa perspectiva, ele seria o resultado da genialidade criativa do autor, expressando o homem em sua atividade artística. Por isso, o estudo estilístico ficou circunscrito às obras literárias e aos estilos de época. Muitos estudos foram desenvolvidos, considerando as transformações ocorridas na linguagem literária desde a Antiguidade.

$\mathrm{Na}$ época Clássica, o estilo obedecia ao modelo instituído de acordo com os três gêneros delimitados por Aristóteles: lírico, épico e dramático. Cada um deles também apresentava variantes que eram reconhecidas pela forma. Assim, o autor já tinha como orientação uma forma estável na elaboração de seus textos.

Com o Romantismo e a ênfase atribuída ao sujeito criador, como autoridade máxima de seu discurso, tais formas foram abandonadas em função da imaginação e da originalidade do autor. A partir desse momento, o estilo tornou-se a expressão da genialidade autoral, portanto circunscrito a sua subjetividade. A estilística do século XIX debruçou-se sobre as obras literárias para observar o estilo em sua peculiaridade individual bem como os resultados expressivos materializados na linguagem.

Dentre os autores que se dedicaram a esses estudos, destacam-se Karl Vossler (1872-1949), Leo Spitzer (1887-1960), representantes da estilística alemã e os espanhóis Dámaso Alonso (1898-1990), Amado Alonso (1896 -1952) e Carlos Bousoño (1923-2015), entre outros. Vossler, um filólogo comparatista alemão, no início do século XX, seguindo os passos de Humboldt, dedica-se ao estudo da evolução das línguas e das formas literárias. Em suas investigações, dedica-se às formas literárias da Antiguidade e dos povos românicos, observando, nas formas poéticas românicas, a originalidade na imitação dos modelos gregos. Sua obra Formas literarias en los pueblos románicos (1944) apresenta uma coletânea de artigos sobre essa temática. Apesar de considerar o estilo numa concepção mais ampla porque observa a época e os costumes, apresenta uma visão ainda romântica, porque considera o estilo como inspiração ou expressão do homem no texto. Assim, a análise estilística idealista mantém-se ainda numa perspectiva de estrato romântico.

Contrapondo-se a essa visão individualista no estudo da língua, um movimento contrário, visando à objetividade científica, procura descrever a língua em sua constituição concreta, evidenciando os elementos de sua composição, nos moldes 
dos estudos das ciências naturais. Saussure, responsável por essa vertente, instaura, então, uma teoria linguística que bane qualquer interferência da expressividade em sua descrição. A fala (parole) não faz parte de sua investigação por considerá-la fora do âmbito de uma análise científica pela sua abrangência e idiossincrasia.

Nesse cenário do início do século XX, os intelectuais que compõem o Círculo bakhtiniano, oriundos de várias áreas do conhecimento, procuram discutir a linguagem de modo mais abrangente, questionando as duas vertentes teóricas, vigentes na época: a estilística vossleriana e a linguística saussureana. Ainda que Bakhtin e o Círculo respeitem essas duas vertentes teóricas, destacando seus aspectos positivos, pontuam também, de modo incisivo, suas limitações. Entendem que ambas são insuficientes para o estudo da linguagem no campo da comunicação: a linguística, pela forma abstrata com que observa a língua, distanciando-se de sua dinamicidade viva; a estilística, por restringir os estudos às peculiaridades subjetivas, portanto limitadas.

Com base na proposição bakhtiniana de estilo, foi selecionado, para esta reflexão, o artigo de opinião "Notas sem confete", de Fernando de Barros e Silva, veiculado na Folha de S. Paulo, de 6 de fevereiro de 2008, a fim de compreender como o tema, a proposta do autor e sua relação com o contexto imediato criam uma forma expressiva diferenciada, rompendo com a forma composicional e o estilo genérico do artigo.

No cumprimento dessa proposta, inicia-se pela discussão da teoria discursiva de Bakhtin e o Círculo, no que se refere a gênero, estilo e peculiaridade autoral, confrontando o pensamento bakhtiniano com as teorias vigentes do início do século XX. A seguir, analisa-se o artigo de opinião selecionado, conduzindo-se à conclusão de que o gênero discursivo, na perspectiva do Círculo, apresenta peculiaridades do ponto de vista estilístico que impedem a configuração mecanicista de modelos genéricos.

\section{A teoria dialógica da linguagem}

Ao refletir sobre a linguagem em sua realidade concreta, como meio interativo de comunicação, Bakhtin e o Círculo compõem uma teoria ampla, cujas categorias vão sendo gestadas ao longo do tempo, num movimento dialógico constante, como exercício prático da teoria que sustentam: sua dialogicidade. $\mathrm{O}$ princípio norteador dessa vertente é a concepção interativa de linguagem em sua duplicidade constitutiva.

Desse modo, procuram superar os limites apontados nas duas teorias existentes, a linguística saussureana e a estilística alemã, ou seja, o distanciamento teórico, 
que conduz à abstração na descrição da língua como objeto, e o isolamento idealista, cuja configuração de língua fica circunscrita à subjetividade do autor. Ao considerar a natureza social da linguagem, própria da comunicação humana, e as relações dialógicas inerentes a esse processo, desviam o enfoque para a concretização da linguagem em enunciados concretos, cujos limites se expandem para além das fronteiras do texto, inserindo-os na cadeia discursiva. A palavra, então, ao ser enunciada, passa a ser um elo nessa cadeia (BAKHTIN, 2003), como resultado da relação do eu com o outro, portanto do sujeito com o contexto social que o outro representa. Nessa perspectiva, para ilustrar a teoria, lançam mão da imagem de Jano, cuja face ilustra tal duplicidade: uma voltada para a natureza peculiar do sujeito e a outra para o outro exterior, internamente constituído (BAKHTIN/VOLOCHÍNOV, 2006).

Nessa concepção fundante, vão sendo discutidos conceitos, cuja terminologia coincide com a de outras teorias, mas delas se distanciam, como é o caso de enunciado, enunciação, enunciado concreto, em oposição aos conceitos gramaticais de frase, período, oração, considerados como a matéria inerte de que o enunciador lança mão para a concretização expressiva da comunicação real, elaborada em enunciados concretos.

Com essa nova abordagem, tais pesquisadores modificam os conceitos antigos dos gêneros, concebidos por Aristóteles. Tais gêneros foram descritos com o objetivo de delimitar especificidades no campo da produção artística: lírico, épico e dramático. Tal definição, muito adequada a uma sociedade voltada para a produção artística de uma elite letrada, não atende às múltiplas formas de produção enunciativa numa sociedade que evoluiu no campo industrial, tecnológico e comunicativo, muito mais dinâmica e complexa.

Assim, a concepção de gêneros discursivos, conceituados por Bakhtin e o Círculo, representa uma forma de adaptação teórica à realidade social contemporânea, cujos gêneros se proliferam em função das necessidades imediatas de comunicação, tanto do enunciador quanto do leitor presumido, propiciando o aparecimento de múltiplos exemplares genéricos nem sempre condizentes com o repertório conhecido. Como afirma o filósofo da linguagem:

A riqueza e a diversidade dos gêneros discursivos são infinitas porque são inesgotáveis as possibilidades da multiforme atividade humana e porque em cada campo dessa atividade é integral o repertório de gêneros de discurso, que cresce e se diferencia à medida que se desenvolve e se complexifica um determinado campo. (BAKHTIN, 2003, p.262). 
Desse modo, Bakhtin parece intuir a necessidade dessa peculiaridade que, talvez na época, não fosse ainda tão significativa, embora, em suas pesquisas sobre o romance, tivesse demonstrado como esse novo gênero abriga gêneros diversos. Sob esse aspecto, Bakhtin demonstra que os gêneros se transformam e se adaptam às exigências do contexto de produção, de circulação e de recepção.

Sendo assim, a conceituação dos gêneros discursivos, por Bakhtin e o Círculo, atende ao contexto contemporâneo, em que os gêneros se proliferam, integrando, modificando, alterando peculiaridades composicionais e estilísticas em função de necessidades imediatas. Entendidos como formas socialmente elaboradas em função da esfera de atividade humana, apresentam características intrínsecas, descritas detalhadamente no ensaio sobre os gêneros discursivos em Estética da criação verbal (BAKHTIN, 2003). Uma das características principais é a existência de gêneros discursivos primários, menos elaborados que atendem às necessidades imediatas de comunicação; e os secundários, muito elaborados porque surgem em situações de comunicação mais complexas e desenvolvidas. Sob esse aspecto, os gêneros secundários, ao se formarem,

[...] incorporam e reelaboram diversos gêneros primários (simples), que se formaram nas condições da comunicação discursiva imediata. Esses gêneros primários, que integram os complexos, aí se transformam e adquirem um caráter especial: perdem o vínculo imediato com a realidade concreta e os enunciados reais alheios: por exemplo, a réplica do diálogo cotidiano ou da carta no romance, ao manterem a sua forma e o significado apenas no plano do conteúdo romanesco, integram a realidade concreta apenas através do conjunto do romance, ou seja, como acontecimento artístico literário e não da vida cotidiana. (BAKHTIN, 2003, p.264).

Sendo assim, é fundamental considerar os elementos constitutivos do gênero discursivo, conforme pontua Bakhtin, para entender melhor como eles se organizam nas esferas de produção, circulação e recepção. Cada gênero discursivo apresenta um tema, em função da proposta comunicativa do gênero e da proposta enunciativa de cada enunciador, o que determina sua forma composicional e seu estilo. Assim, a forma composicional constituída pela materialidade linguística segue mais ou menos o formato de cada gênero, mas de modo a atender as necessidades expressivas de cada autor. De modo semelhante, o estilo e o tema atendem às imposições do gênero, o estilo genérico. Entretanto, o estilo não se reduz ao gênero, também apresenta peculiaridades próprias de cada enunciador.

Nessa perspectiva, a concepção de estilo se distancia da estilística idealista centrada apenas no sujeito, embora este desempenhe um papel importante na 
Linha D’Água (Online), São Paulo, v. 28, n. 2, p. 172-189, dez 2015

elaboração do enunciado. Desse modo, os gêneros discursivos apresentam aspectos irredutíveis a uma classificação simplificada ou esquematizada. Como pontua Bakhtin:

O estudo da natureza dos enunciados e dos gêneros discursivos é, segundo nos parece, de importância fundamental para superar as concepções simplificadas da vida do discurso, do chamado "fluxo discursivo" da comunicação, etc., daquelas concepções que ainda dominam a nossa linguística. Além do mais, o estudo do enunciado como unidade real da comunicação discursiva permitirá compreender de modo mais correto também a natureza das unidades da língua (enquanto sistema) - as palavras e orações. (BAKHTIN, 2003, p.269, grifos do autor).

Observa-se, nesse recorte, a valorização das peculiaridades linguísticas do texto, mas sempre tendo em vista as relações dessa materialidade constitutiva do texto com o gênero, a proposta comunicativa do enunciador e seu tom valorativo que expressa seu estilo. Para entender melhor como o estilo é concebido pela teoria dialógica, é preciso recuperar alguns conceitos que têm por fundamento a constituição da dialogia intrínseca da linguagem.

Como já foi apontado, da perspectiva bakhtiniana, o sujeito-enunciador se constitui pela linguagem na relação entre o eu e o outro. $\mathrm{O}$ outro resulta da relação do sujeito com o contexto externo, tanto pelas palavras que recebe e que o constituem, quanto pela sua relação com o ambiente exterior. A palavra é concebida em sua duplicidade: voltada para a interioridade do sujeito, que dela se apropria, e voltada para o exterior como resposta refratada desse sujeito ao contexto sócio-histórico imediato (BAKHTIN; VOLOCHÍNOV, 2006).

Esse é o princípio gerenciador que sustenta toda a teoria dialógica da linguagem, opondo-se ao subjetivismo individualista da estilística alemã, representada por Vossler, Spitzer e Lorck, entre outros. Na perspectiva dessa estilística, a linguagem é um ato puramente individual, como expressão de uma consciência, com "seus desejos, suas intenções, seus impulsos criadores, seus gostos, etc." (BAKHTIN; VOLOCHÍNOV, 2006, p.114).

Contrapondo-se a essa teoria, Bakhtin/Volochínov argumenta que a expressão gerada na consciência do sujeito, no seu psiquismo, exterioriza-se de modo objetivo para o outro "com a ajuda de algum código de signos exteriores. A expressão comporta, portanto, duas facetas: o conteúdo (interior) e sua objetivação exterior para outrem (ou também para si mesmo)."(BAKHTIN; VOLOCHÍNOV, 2006, p. 115).

Como a linguagem não nasce do indivíduo, mas é fruto de uma tradição sócio-cultural, ao apropriar-se dela, o enunciador é obrigado a respeitar as suas 


\section{Linha D'Água (Online), São Paulo, v. 28, n. 2, p. 172-189, dez 2015}

regras, reagindo a elas de acordo com a necessidade de cada momento. Nas palavras desses teóricos,

[...] exteriorizando-se, o conteúdo interior muda de aspecto, pois é obrigado a apropriar-se do material exterior, que dispõe de suas próprias regras, estranhas ao pensamento interior. No curso do processo de dominar o material, de submetê-lo, de transformá-lo em meio obediente, da expressão, o conteúdo da atividade verbal a exprimir muda de natureza e é forçado a um certo compromisso. (BAKHTIN; VOLOCHÍNOV, 2006, p.115)

Sob esse aspecto, toda enunciação é determinada pelas condições exteriores, pelo contexto social imediato, como produto da interação de dois indivíduos, pois o enunciado se dirige a alguém e é em função dessa orientação que ele se concretiza. Como pontua Bakhtin/Volochínov,

[...] a personalidade que se exprime, apreendida, por assim dizer, do interior, revela-se um produto total da inter-relação social. A atividade mental do sujeito constitui, da mesma forma que a expressão exterior, um território social. Em consequência, todo o itinerário que leva da atividade mental (o "conteúdo a exprimir") à sua objetivação externa (a "enunciação") situa-se completamente em território social. (BAKHTIN; VOLOCHÍNOV, 2006, p. 121-122)

É desse movimento interativo que o estilo se constitui, tanto no que diz respeito ao gênero discursivo, quanto no que diz respeito à proposta individual de expressão. Pensando a questão dos gêneros discursivos, Medviédev, antecipando a conceituação bakhtiniana, afirma que os gêneros são formas de comunicação já estabelecidas na consciência do ser humano. Assim, a linguagem é o meio de expressão que representa os

[...] atos de orientação do homem na realidade, que são interiores, íntegros e expressos de modo material, assim como as formas desses atos, são extremamente importantes. É possível dizer que a consciência humana possui uma série de gêneros interiores que servem para ver e compreender a realidade. Dependendo do meio ideológico, uma consciência é mais rica em gêneros, enquanto outra é mais pobre. (MEDVIÉDEV, 2012, p. 198)

Em sua concepção mais abrangente do enunciado concreto na forma genérica, Bakhtin acentua a entonação como expressão da individualidade do sujeito, de 


\section{Linha D'Água (Online), São Paulo, v. 28, n. 2, p. 172-189, dez 2015}

seus valores, de seu posicionamento axiológico diante da vida. Também explicita as peculiaridades do gênero, consideradas essenciais em sua constituição, ou seja, o tema, a forma composicional e o estilo.

$\mathrm{Na}$ concepção do gênero discursivo, além do tema gerenciador, da forma composicional que o constitui, Bakhtin atribui ao estilo a capacidade de estruturação do gênero responsável por sua estabilidade. Contudo, a inflexão do sujeito-enunciador possibilita variações, flutuações em função do seu tom avaliativo e das condições de produção. Sob esse aspecto, o gênero não se estrutura numa camisa de força, sendo por isso considerado como "relativamente estável" (BAKHTIN, 2003), pois ele acompanha a evolução social e as novas necessidades de comunicação.

Essa é a grande diferença que se estabelece entre a proposição bakhtiniana e a estilística individualista, mais adequada à análise dos gêneros literários em que o estilo do autor é analisado em suas idiossincrasias. Sob a ótica do Círculo, o estilo abrange todos os gêneros discursivos, em graus variáveis: mais determinado e invariável nos gêneros instituídos de modo mais objetivo e impessoal, como a correspondência oficial ou os documentos burocráticos; e os mais variáveis, em função da infiltração da subjetividade expressiva, como os textos literários, jornalísticos ou publicitários, entre outros. Nesse aspecto, o filósofo da linguagem lembra que

Quanto melhor dominamos um gênero tanto mais livremente os empregamos, tanto mais plena e nitidamente descobrimos neles a nossa individualidade (onde isso é possível e necessário), refletimos de modo mais flexível e sutil a situação singular da comunicação; em suma, realizamos de modo mais acabado o nosso livre projeto de discurso. (BAKHTIN, 2003, p. 285).

Com esse comentário, Bakhtin amplia tanto o conceito como o formato que os diversos gêneros apresentam, escapando dos modelos estratificados pelo uso. Entretanto, por serem constituídos pela linguagem, são submetidos à suas coerções:

Os gêneros do discurso, comparados às formas da língua, são bem mais mutáveis, flexíveis e plásticos; entretanto, para o indivíduo falante eles têm significado normativo, não são criados por ele mas dados a ele. Por isso um enunciado singular, a despeito de toda a sua individualidade e do caráter criativo, de forma alguma pode ser considerado uma combinação absolutamente livre de formas da língua, como supõe, por exemplo, Saussure (e muitos outros linguistas que o secundam) que contrapõe enunciado (la parole) como ato puramente individual ao sistema da língua como fenômeno puramente social e obrigatório para o indivíduo. (BAKHTIN, 2003, p. 285). 
Nesse comentário, Bakhtin evidencia não apenas as limitações e coerções que a própria língua impõe ao falante, mas procura analisar a produção enunciativa em relação ao momento e às condições de produção, bem como à proposta do sujeito enunciador, para o qual a língua também oferece escolhas e possibilidades múltiplas de combinação. É nesse espaço que o estilo individual atua, muitas vezes forçando, impondo novas formas de produção genérica.

\section{A questão da autoria}

$\mathrm{Na}$ perspectiva dialógica do discurso, o enunciador representa o sujeito produtor de enunciados, que imprime a eles sua assinatura, e, sob esse aspecto, distancia-se do autor-pessoa em sua atividade rotineira. No momento que o sujeito se propõe a escrever, esboça uma proposta comunicativa e, em função dela, organiza seu pensamento, escolhe o gênero que melhor atenda a essa proposta, passando a elaborar seu enunciado em função de um leitor pressuposto e do meio de divulgação desse enunciado. Todo esse conjunto exige o distanciamento do sujeito para a organização de seu projeto enunciativo. Para explicitar melhor tal processo criativo, Bakhtin lança mão de dois conceitos basilares: compenetração e exotopia. No ensaio $\mathrm{O}$ autor e a personagem na atividade estética, elaborado na década de vinte e publicado em Estética da criação verbal (2003), o filósofo da linguagem expõe o processo de criação do autor em relação à obra literária. Segundo ele, o momento de criação de uma personagem exige uma proximidade máxima do autor em relação à criatura, um movimento de empatia e compenetração para vivenciar sua identidade de modo completo, mas dentro dos limites impostos pela alteridade criadora. Tal compenetração deve ser transgrediente, porque o autor, em sua criação, deve dar acabamento estético a esse objeto, por isso não pode permanecer fundido a ele. Deve percebê-lo em sua totalidade como ser autônomo. Só o artista é capaz de dar acabamento a sua criação. Ele conhece sua personagem integralmente, interage com ela e dela se distancia para representá-la artisticamente.

Em sua explanação, Bakhtin se refere à obra artística, mas a concepção exotópica pode ser ampliada para outras formas de comunicação. Tal possibilidade fica evidente no ensaio $\mathrm{O}$ problema do texto na linguística, na filologia e em outras ciências humanas, publicado em Estética da criação verbal (2003), quando ele trata do posicionamento do pesquisador diante do objeto de sua pesquisa. Nesse texto, a visão exotópica desse sujeito é enfatizada, considerando o distanciamento necessário para transmissão de sua pesquisa. Mas o primeiro momento do pesquisador, em relação ao objeto pesquisado, como Bakhtin destaca, é de envolvimento e empatia necessários para a compreensão do objeto. Já em uma segunda etapa, o 
distanciamento torna-se fundamental para a compreensão de seus resultados e de sua exposição em relatos. Marília Amorim (2004) explicita essa relação ambivalente do pesquisador com sua pesquisa a partir das considerações tecidas por Bakhtin:

A alteridade sob a forma de diálogo e da citação é pois o traço fundamental da linguagem. Não há linguagem sem que haja um outro a quem eu falo e que é ele próprio falante/respondente; também não há linguagem sem a possibilidade de falar do que o outro disse. (AMORIM, 2004, p. 97)

Assim, as relações dialógicas, que decorrem da relação eu-outro, são constitutivas da linguagem e de todo e qualquer discurso e é por meio dessas relações que o autor conclui seu enunciado. Para que o acabamento se concretize de modo satisfatório, é preciso que o autor consiga distanciar-se de seu objeto de modo a concebê-lo em sua totalidade enunciativa.

A visão extraposta do pesquisador representa o distanciamento necessário para concluir sua pesquisa. De modo semelhante, pode-se pensar na relação do autor-enunciador com seu artigo de opinião. $\mathrm{O}$ autor se identifica com o tema a ser explanado e depois se distancia dele na produção. Na composição do texto, tanto o tom avaliativo quanto a concretização verbal representam o desdobramento dialógico entre o eu e o outro, relação necessária para o acabamento estético do enunciado.

$\mathrm{Na}$ concepção bakhtiniana, a visão de autor é bastante complexa porque está centrada no princípio dialógico constitutivo da linguagem, no lugar situado do autor diante de seu contexto sócio-histórico, com o qual interage, respondendo a ele em concordância ou dissonância. Tal posicionamento afeta, de modo crucial, sua linguagem expressa em gêneros discursivos. Portanto, segundo Sobral, interpretando Bakhtin, pensar na autoria implica pensar no contexto complexo em que o enunciador age, envolve considerar, de um lado, o princípio dialógico (o que segue a direção do interdiscurso) e, do outro, os elementos sociais, históricos etc., que formam o contexto da interação. Trata-se, como se pode ver, de elementos que estão imbricados nos próprios discursos, e que só por meio deles nos são acessíveis (SOBRAL, 2012, p. 129).

No texto de 1924, O problema do conteúdo, do material e da forma na criação literária, que compõe a coletânea de ensaios reunidos na obra Questões de literatura e de estética: a teoria do romance, organizado em 1975 e traduzido no Brasil na década de 80 , Bakhtin explicita sua perspectiva teórica de modo mais incisivo, contrapondo-se a uma visão engessada pela peculiaridade classificatória de enunciados literários adotada pelo Formalismo Russo. Nesse ensaio, Bakhtin discute a questão da linguagem em sua dinâmica criativa, mobilizando a língua de modo menos 
estratificado e mais adequado às diversas instâncias comunicativas. Ao pautar os gêneros da esfera literária pela forma, os críticos eliminavam a característica intrínseca à literatura, cuja produção expressa o posicionamento ético/estético do autor.

Como se observa em um de seus primeiros ensaios, Para uma filosofia do ato (2010), Bakhtin discorre sobre a responsabilidade do ato, tanto do escritor quanto de qualquer enunciador realmente integrado em seu papel humano. Nesse texto, o conceito de ética, responsividade ativa do homem diante do mundo e em suas relações com seus semelhantes é o componente que o distingue das atividades mecânicas, da falta de compromisso com a vida, muitas vezes manifestas numa concepção de linguagem automatizada. Tal conceito é retomado no ensaio sobre os gêneros discursivos, na concepção do tom valorativo que perpassa por todos os enunciados e que deve ser o traço que distingue o posicionamento do enunciador diante do tema, de sua elaboração, manifestando-se de modo mais acentuado no estilo. Como afirma Bakhtin:

O segundo elemento do enunciado que the determina a composição e o estilo, é o elemento expressivo, isto é, a relação subjetiva emocionalmente valorativa do falante com o conteúdo do objeto e do sentido do seu enunciado. Nos diferentes campos da comunicação discursiva, o elemento expressivo tem significado vário e grau vário de força, mas existe em toda parte: um enunciado absolutamente neutro é impossível. (BAKHTIN, 2003, p. 289, grifo do autor).

Por esse comentário, percebe-se a importância dada ao tom valorativo e ao estilo do enunciador na concretização enunciativa. Pelo tom valorativo, o autor posiciona-se axiologicamente com o contexto social. É todo esse conjunto de elementos que deve ser observado no enunciado concreto. De certo modo, é ele o responsável pela sua configuração genérica. $\mathrm{O}$ estilo, então, passa a ser considerado em sua duplicidade constitutiva, do autor com o seu grupo social, como expressa Volochínov, contestando a afirmação de Buffon, para quem "o estilo é o homem":

[...] o estilo são pelo menos dois homens, ou mais exatamente, é o homem e seu grupo social na pessoa de seu representante ativo - o ouvinte, que é o participante permanente do discurso interno e externo do homem. (VOLOCHÍNOV, 2013, p. 97).

Sob esse prisma, entendemos que o artigo de Fernando de Barros, publicado no período de Carnaval, ilustra, de modo exemplar, as relações de estilo e autoria 
Linha D'Água (Online), São Paulo, v. 28, n. 2, p. 172-189, dez 2015

na composição de gêneros discursivos a partir da perspectiva discursiva dialógica da linguagem.

\section{Artigo de opinião e estilo}

O artigo de opinião, que circula na esfera jornalística, é um gênero concebido no formato dissertativo, ou seja, o redator defende um ponto de vista com argumentos convincentes, expressos numa linguagem adequada ao público-leitor do veículo. Na Folha de S. Paulo, os artigos ocupam a segunda página do jornal, e os articulistas selecionados mantêm uma produção regular com espaço reservado a cada um deles, onde expressam sua opinião sobre fatos noticiados na imprensa. $\mathrm{O}$ artigo normalmente obedece ao formato dissertativo, com introdução, argumentação e conclusão, numa linguagem clara e coesa. Apesar de o estilo individual variar em função de cada articulista, existe certo padrão exigido pelo jornal. Sob esse aspecto, o artigo "Notas sem confete" escapa ao formato regular dos artigos publicados nesse espaço, como a sua reprodução abaixo evidencia:

Notas sem confete

São Paulo- Embora essa forma de crítica tenha caído em desuso - ou por isso mesmo-, seguem alguns rascunhos sobre cultura e sociedade (e uma pitada de política) colhidos a esmo no carnaval.

Nunca, como na nossa época, o sujeito comum foi tão impelido a se projetar nas celebridades que consome pela mídia. $\mathrm{O}$ sucesso de um programa boçal como o "Big Brother" talvez resida aí: ele materializa essa projeção por meio de uma espécie de novela da vida real. Plim, plim: Zé do Povo virou "celebrity".

No Carnaval se passa o mesmo, mas com sinais trocados: as celebridades brincam de "ser povo". E assim reafirmam a sua...celebridade.

A "cultura das celebridades", essa ficção, colonizou o Carnaval. As escolas de samba passaram a funcionar como agências de "rating" de modelos e aspirantes. Fazem a triagem que alimenta o mercado sexista e vulgar de revistas, novelas e filhos da elite pelo resto do ano. 


\section{Linha D'Água (Online), São Paulo, v. 28, n. 2, p. 172-189, dez 2015}

Com "tanto riso, tanta alegria e mais de mil palhaços no salão", difícil eleger um artista. Destaque para o filósofo da África, Nizan Guanaes, curvando-se para beijar a mão do governador Jaques Wagner, ao lado do presidente da Coca-Cola.

Galãzinho global, Cauã faz a barba diante das câmeras para uma empresa instalada no camarote de Flora Gil, mulher do ministro da Cultura. Recebe R\$30 mil pela mise-en-scène. No maior "Baticum”.

As áreas Vips dos camarotes entraram em crise, informa Mônica Bergamo. Celebridades não querem mais emprestar seu prestígio às cervejarias assim, de graça.

Sugestão para 2009: cada representante da cultura nacional pendura uma etiqueta na camisa com seu valor de mercado: “Eu custo $\mathrm{R} \$$ ”. Os mais descolados podem inovar: "Estou grátis”. Será fashion. (BARROS E SILVA, 06 fev.2008, p.A2).

À primeira vista, o texto causa impacto pelo ineditismo estrutural. Como o título propõe, o artigo é elaborado em formato de notas, portanto já desvinculado da organização sequencial de um artigo. No próprio título, a menção a "sem confete", já faz remissão ao momento de produção: período de carnaval. Como o autor menciona no início, "seguem alguns rascunhos sobre cultura e sociedade (e uma pitada de política) colhidos a esmo no carnaval” (BARROS E SILVA, 06 fev.2008, p.A2). A proposta é mesmo apontar comportamentos e atitudes de celebridades e da população como reflexo da alienação diante dos problemas do país. Portanto, o tema deste artigo é uma crítica à sociedade do espetáculo e do consumo. Em função desse tema e do contexto carnavalesco, momento que a população está muito mais preocupada com a diversão do que com a leitura, o autor procura agilizar a redação de seu artigo, pontuando cenas expressivas para o seu comentário crítico.

O título metonímico está integralmente relacionado com o formato e com a proposta do autor. Tomando uma atitude responsiva em relação ao leitor, o enunciador relaciona as notas a confetes lançados à população, mas contra a expectativa, elas são sem confete. Nesta última acepção, "confete" pode ser considerado como festejo, aplauso. $\mathrm{Na}$ contramão da alegria contagiante da festa, o autor apresenta ao leitor cenas do cotidiano que demonstram a irresponsabilidade dos cidadãos com a crise político-econômica do país.

Várias são as informações referentes aos gastos do governo, às transações econômicas de venda de estatais em benefício de um grupo privilegiado. A Folha de S. Paulo de 02 de fevereiro de 2008 noticia a articulação de políticos Andrade e 
Jereissati com a Fundação Atlântico (fundo de pensão dos funcionários da OI) na compra da BrT pela OI, ficando os empresários com 49\% das ações. Também, há referência a benefícios usufruídos pelo filho de Lula em transações comerciais. Além disso, os escândalos do Mensalão continuavam ecoando pela leniência do processo no STJ e pela polêmica que polarizava o debate público em torno do assunto. Portanto um problema mal resolvido.

Por outro lado, a superficialidade no comportamento da população que usufruía dos benefícios do real supervalorizado, a preocupação com a imagem visual, com a beleza e com a ostentação de felicidade artificial encobriam os problemas reais que o país enfrentava.

Como o enunciador pontua, "Nunca, como na nossa época, o sujeito comum foi tão impelido a se projetar nas celebridades que consome pela mídia."(BARROS E SILVA, 06 fev.2008, p.A2). Com esse comentário, Fernando de Barros expressa seu posicionamento no cenário cultural do país. Numa comemoração popular como o Carnaval, o requinte e o comportamento das celebridades servem de parâmetro para o homem comum. Faz referência a comportamentos subservientes, como o de Nizan Guanaes: "curvando-se para beijar a mão do governador Jaques Wagner, ao lado do presidente da Coca-Cola." (BARROS E SILVA, 06 fev.2008, p.A2). Recupera as palavras de Mônica Bergamo, jornalista conceituada, que menciona a exigência de celebridades de cachês elevados para exposição da imagem. Faz menção a Flora Gil, mulher do ministro da cultura na época (Gilberto Gil), recebendo Cauã em seu camarote. Esse cenário VIP, em uma festa popular como o Carnaval, expõe o descompasso entre a elite social do país e a população.

$\mathrm{O}$ artigo é composto em fragmentos breves, com exemplos de atitudes de artistas que vendem sua imagem para exposições nos camarotes de produtos montados na avenida do desfile de escolas de samba cariocas, exigindo cachês altíssimos, para a simples presença nesse espaço. Assim, os comentários denotam a ironia do autor, como no trecho: "Com 'tanto riso, tanta alegria e mais de mil palhaços no salão', difícil eleger um artista.” (BARROS E SILVA, 06 fev.2008, p.A2). O trecho da marchinha carnavalesca de Zé Keti e Pereira Mattos, "Máscara negra", lançada em 1967, em plena ditadura militar, é recuperado para estabelecer um diálogo com a situação que o articulista registra. Menciona alguns exemplos, como o do ator Cauã que, para marcar sua presença num camarote, cobra um alto cachê: "Recebe R\$ 30 mil pela mise-en-scène. No maior 'Baticum'." (BARROS E SILVA, 06 fev.2008, p.A2).

As referências ilustrativas servem como argumentos para demonstrar a falta de responsabilidade dos ídolos culturais com a realidade da população do país, em sua maioria composta por cidadãos que ganham salários baixos e que vivem 
em condições precárias de sobrevivência. Diante desse contexto, cobrar um cachê exorbitante pela simples exposição de sua imagem parece uma afronta. $\mathrm{O}$ dinheiro fácil, ganho sem nenhum esforço, passa a ser o ideal sonhado pela população, por isso não cobrar nada seria totalmente inovador. Assim o autor conclui seu artigo ironicamente: "Os mais descolados podem inovar: 'Estou grátis'. Será fashion".

Esse artigo, elaborado fora do limite convencional do jornal Folha de S. Paulo, apresenta uma forma composicional inédita, alterando seu estilo genérico. Segundo a teoria bakhtiniana, os gêneros apresentam formato "relativamente estável", em função do contexto. Assim, o progresso tecnológico, a proposta comunicativa do enunciador, o tema e as necessidades do leitor presumido podem incidir sobre a forma composicional e o estilo genérico de enunciados, como ocorre com esse artigo de Fernando de Barros. Como pontua Bakhtin:

O estilo é indissociável de determinadas unidades temáticas e - o que é de especial importância - de determinadas unidades composicionais: de determinados tipos de construção do conjunto, de tipos do seu acabamento, de tipos da relação do falante com outros participantes da comunicação discursiva - com os ouvintes, os leitores, os parceiros, o discurso do outro, etc. O estilo integra a unidade de gênero do enunciado como seu elemento (BAKHTIN, 2003, p. 266).

Elaborado em um momento especial, em que a atenção do leitor está voltada para os festejos carnavalescos, um artigo nos moldes estabelecidos pela imprensa seria pouco atrativo para o leitor. Desse modo, o articulista, respondendo às necessidades do imediatismo momentâneo de seu público leitor, quebra a estruturação sintática de um texto dissertativo sem deixar de apresentar sua tese, seus argumentos e sua conclusão. Aparentemente fragmentado, como se estabelece a coesão entre as partes de modo a sustentar a tese defendida pelo autor? Seria um texto frouxo, por sua estruturação? Como se pode observar, as diversas partes que o constituem mantêm uma relação intrínseca de sentido pelo conteúdo que expressam. $\mathrm{O}$ impacto pela inovação é provocativo para atingir o destinatário num momento de descontração e de pouca disponibilidade para leitura de textos mais complexos.

Para entender melhor o tema desse enunciado, é preciso recuperar dados do contexto político econômico do país naquele momento. As notícias veiculadas na época mencionam os negócios lucrativos do filho de Lula e uso do cartão corporativo de forma abusiva por membros do governo. Deve-se mencionar que 2008 representa a metade do segundo mandato de Lula, após os escândalos do mensalão e da malversação do dinheiro público. Os gastos com projetos sociais, de natureza populista, também ajudaram a reeleição do então presidente, onerando os cofres 
públicos. Medidas de contenção de despesas de cortes de salários eram discutidas como recurso para conter os gastos, inclusive com o rombo do INSS, exigindo medidas drásticas que afetariam as aposentadorias e os salários dos aposentados. Muitos problemas começaram a surgir, anunciando a crise que desencadearia nos anos posteriores.

Portanto, Fernando de Barros e Silva, articulista veterano da Folha de S. Paulo, procura alertar o leitor sobre os problemas minimizados num momento de euforia, mas cujos desdobramentos seriam melancólicos. As vozes com as quais Barros dialoga, vindas do passado, sinalizam o futuro. A referência à marchinha "Máscara Negra” explora a ambiguidade necessária para manter as relações dialógicas entre momentos afastados temporalmente, mas próximos culturalmente. Os "palhaços do salão" do passado e do presente podem ser tanto os foliões como a população enganada e explorada por uma elite descompromissada com o futuro do país. Como afirma Bakhtin (2003), o enunciado entra na cadeia discursiva, recuperando o passado e projetando-se no futuro.

\section{Conclusão}

Com essa exposição, confirma-se a tese de que "quanto melhor dominamos os gêneros tanto mais plena e nitidamente descobrimos neles a nossa individualidade" (BAKHTIN, 2003, p.285). O estilo, então, só pode ser considerado nessa relação com o gênero e com a proposta de comunicação do enunciador, por meio da qual expressa seu posicionamento axiológico diante do contexto social, expressando seus valores, sua perspectiva crítica diante dos fatos. Fernando de Barros, nesse artigo, extrapola o formato genérico, ditado pelas normas jornalísticas, em função das circunstâncias sociais e do público leitor do jornal. Expressa, na materialidade linguística, o tom de crítica social inerente ao artigo de opinião, abdicando do estilo genérico que o constitui.

Adequando seu enunciado ao momento, o autor demonstra sua competência e seu domínio do gênero, transgredindo seu formato.

Desse modo, é possível concluir que, na análise de enunciados concretos, é preciso considerar todo o contexto de produção, a proposta autoral e o horizonte social do público a que se dirige. Naturalmente, no caso desse artigo, há um público leitor capaz de entendê-lo e interpretá-lo, embora fique surpreso pelo ineditismo de sua estruturação. E é essa justamente a proposta do autor, mobilizar o leitor de modo a levá-lo a refletir sobre o contexto sócio-cultural do país e de seus cidadãos, num momento de total descontração. Só assim é possível 
Linha D'Água (Online), São Paulo, v. 28, n. 2, p. 172-189, dez 2015

entender o estilo do autor e o gênero discursivo na perspectiva dialógica da linguagem.

\section{Referências}

AMORIM. M. O pesquisador e seu outro: Bakhtin nas Ciências Humanas. São Paulo: Musa, 2004. . Cronotopo e exotopia. In: BRAIT. B. (Org.) Bakhtin: outros conceitos chave. São Paulo: Contexto, 2006, p.95-114.

BAKHTIN, M. M. Gêneros discursivos. In: Estética da criação verbal. Trad. Paulo Bezerra. São Paulo: Martins Fontes, 2003, p. 261-306.

- Questóes de estilistica no ensino da língua. Trad. Sheila Grillo e Ekaterina Vólkova Américo. São Paulo: Editora 34, 2013.

. Para uma filosofia do ato responsável. Trad.Valdemir Miotello \& Carlos Alberto Faraco. São Carlos: Pedro \& João Editores, 2010.

; VOLOCHÍNOV, V. Marxismo e filosofia da linguagem: problemas fundamentais do método sociológico na ciência da linguagem. Trad. Michel Lahud e Yara Frateschi Vieira. 12.ed. São Paulo: Hucitec, 2006.

BARROS E SILVA, F. Notas sem confete. Folha de S. Paulo, São Paulo, 6 fev. 2008, p.A2.

MEDVIÉDEV, P. N. O método formal nos estudos literários: introdução crítica a uma poética sociológica. Trad. Ekaterina Vílkova Américo e Sheila Camargo Grillo. São Paulo: Contexto, 2012.

SOBRAL, A. U. A concepção de autor do "Círculo Bakhtin, Medvedev, Voloshinov": confrontos e definições. Macabéa, Crato, v.1, n. 2, p. 123-142, dez/2012.

VOLOCHÍNOV, V.N. A construção da enunciação e outros ensaios. Trad. João Wanderley Geraldi, supervisão Valdemir Miotello. São Carlos: Pedro \& João Editores, 2013.

VOSSLER, K. Formas literarias en los pueblos románicos. Trad. do alemão Carlos Clavería.2.ed. Buenos Aires: Espaso-Calpe Argentina S/A, 1944. 
Linha D’Água (Online), São Paulo, v. 28, n. 2, p. 172-189, dez 2015

. Filosofía del lenguaje. Traducción y notas de Amado Alonso y Raimundo Lida.5.ed. Buenos Aires: Editorial Losada, S/A, 1968[1923].

Recebido: 09/10/2015

Aprovado: 16/11/2015 